\title{
JUURNAL.RU
}

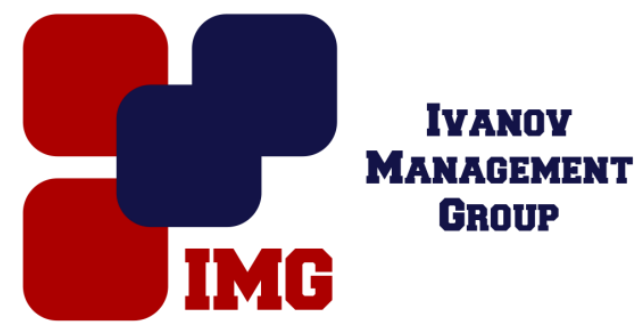

Кириллова А.С.

Северо-Восточный государственный университет Магадан, Россия

doi: 10.18411/lj-31-07-2017-13

idsp 000001:1j-31-07-2017-13

\section{Типы рифм в «Новых стихотворениях» Р.М. Рильке}

Рифма - одно из ключевых понятий поэтической теории и практики и вместе с тем одно из самых дискуссионных в поэтике. Широко обсуждаются среди ученых различные проблемы, связанные с природой рифмы: ее сущность, пределы, классификация, эволюция и изменение рифмы на протяжении ряда эпох, своеобразие способов сочетания рифм у разных поэтов.

Основная задача рифмы - служить одним из важных показателей и семантических опор поэзии. Рифма делит строки стихотворения на смысловые части, одновременно связывая его воедино. Рифма - это семантически наиболее нагруженное слово.

Материалом исследования в нашей статье послужили рифмы в книге Р.М. Рильке «Новые стихотворения». Многие ученые по праву называют этот сборник одной из величайших вершин поэзии XX в. Во многих работах отмечается также неожиданная новизна этой книги по сравнению с поэтической продукцией до 1907 года. Все без исключения исследователи указывали на большую важность категории вещи в «Новых стихотворениях». Об этом писали, в частности, А. Г. Березина, Р.Р. Чайковский и Е.Л. Лысенкова, Е. ТамахинаПлото и многие другие.

Большая часть первого тома «Новых стихотворений» были действительно «новые» стихотворения - в любом смысле. Ничего подобного ни у самого Рильке, ни в немецкой поэзии вообще до этого не появлялось. Новая эстетическая концепция не отрицала, а лишь дополняла его прежнее воззрение на природу поэтического творчества. 
В нашей работе мы предпринимаем попытку выявить основные типы рифм в первой части «Новых стихотворений» Р.М. Рильке. Мы последовательно рассмотрим все рифмованные стихотворения первой части книги и зафиксируем основные типы использованных поэтом рифм: мужские и женские рифмы, кольцевые, смежные, перекрестные, разорванные, сплетенные рифмы и терцет, которыми пользовался Рильке. При этом мы пользуемся следующими условными обозначениями:

+ - перекрестная рифма; $=-$ смежная рифма; $\neq-$ опоясывающая рифма; \pm - сплетенная рифма; \# - разорванная рифма; $\leq-$ терцет.

В качестве примера рифменной структуры поэтических произведений Рильке мы приводим типы рифм из его стихотворения «Танагра»:

\section{Tanagra}

$$
\begin{gathered}
\text { Erde - Gebärde; + (ж) } \\
\text { gebrannt - Mädchenhand; + (м) } \\
\text { vergangen - langen; = (ж) } \\
\text { hin - Kinn, führend - rührend; } \neq(\mathrm{м}),(\text { ж) } \\
\text { drehen - verstehen - vergehen; } \pm(ж) \\
\text { Figur - nur; \# (м) }
\end{gathered}
$$$$
\text { wunderbarer - klarer; }+(ж)
$$$$
\text { war - Jahr; + (M). }
$$

Подобным образом были описаны все 68 стихотворений первой части названного сборника. На основе проведенного анализа мы составили две таблицы, в которых наглядно представлено количество рифм разных типов. В таблице 1 мы показываем соотношение мужских и женских рифм:

Таблица 1

Количество мужских и женских рифм в «Новых стихотворениях»

\begin{tabular}{|c|c|c|}
\hline $\begin{array}{c}\text { Мужская рифма } \\
\text { М }\end{array}$ & $\begin{array}{c}\text { Женская рифма } \\
\text { Ж }\end{array}$ & Всего \\
\hline 217 & 259 & 476 \\
\hline $46 \%$ & $54 \%$ & $100 \%$ \\
\hline
\end{tabular}

Как видно из таблицы, в первой части «Новых стихотворений» Р.М. Рильке несколько преобладают женские рифмы. Из 476 рифм 259 женские. Это составляет 54\%. Таким образом, можно говорить, что мужские и женские рифмы в «Новых стихотворениях» Рильке используются приблизительно в одинаковой пропорции.

Во второй таблице мы представим количество отдельных типов рифм в рассматриваемых нами стихотворениях: 
Таблица 2

Количество разных типов рифм в «Новых стихотворениях»

\begin{tabular}{|c|c|c|c|c|c|c|}
\hline $\begin{array}{c}\text { Смежная } \\
=\end{array}$ & $\begin{array}{c}\text { Опоясы- } \\
\text { вающая } \\
\neq\end{array}$ & $\begin{array}{c}\text { Перекре-стная } \\
+\end{array}$ & $\begin{array}{c}\text { Разорва- } \\
\text { нная } \\
\#\end{array}$ & $\begin{array}{c}\text { Спле- } \\
\text { тенная } \\
\pm\end{array}$ & $\begin{array}{c}\text { Терцет } \\
\leq\end{array}$ & Всего \\
\hline 50 & 79 & 234 & 16 & 25 & 2 & 406 \\
\hline $12 \%$ & $19,5 \%$ & $58 \%$ & $4 \%$ & $6 \%$ & $0,5 \%$ & $100 \%$ \\
\hline
\end{tabular}

Разное количество рифм в двух таблицах объясняется тем, что в опоясывающих рифмах встречаются как мужские, так и женские рифмы, которые подсчитывались отдельно. То есть одна рифма (мужская или женская) представляла собой два типа рифм.

Как видно из таблицы, наиболее частотным видом рифмы в первой части «Новых стихотворений» является рифма перекрестная. Такой вид рифменной связи слов не считается сложным способом организации парных строк в стихотворении. Перекрестная рифма встречается в каждом стихотворении анализируемой книги, кроме «Mädchen-Klage», «Grabmal eines jungen Mädchens», «Liebes Lied», «Der Tod des Dichters», «Selbstbildnis aus dem Jahre 1906», «Der Mramor-Karren». Кроме того, в книге имеются стихотворения, в которых автор использовал только перекрестную рифму, например: «Sappho an Alkaïos», «Buddha».

На втором месте в количественном отношении «Новых стихотворений» оказалась опоясывающая рифма. Этот тип рифмы также весьма распространен, но обычно он встречается гораздо реже, по сравнению со смежной и перекрестной, но только не у Р.М. Рильке. В «Новых стихотворениях» мы можем ее наблюдать чаще, чем смежную. Первая пара рифмованных строк в этом случае как бы «разбивается», одна ее строка открывает, а другая закрывает четверостишие. Вторая пара размещается между ними и остается неделимой. Применение автором данной системы рифмовки придает стихотворениям особую выразительность.

Третьей по количеству употреблений является смежная рифма. Она считается наиболее распространённой рифмой, но у Р.М. Рильке она встречается реже, чем опоясывающая и перекрестная рифма. Такая рифма идет последовательно, друг за другом, то есть автор сначала «закрывает» одну рифму и только потом переходит к следующей.

Следующими по частотности в «Новых стихотворениях» оказались сплетенная и разорванная рифма. 
Что касается «терцета», который подразумевает наличие трех строк с одинаковой рифмой, то он встречается у Р.М. Рильке только в одном стихотворении «Der Ölbaum-Garten».

Таким образом, рифменный репертуар первой части книги «Новые стихотворения» Р.М. Рильке отличается достаточно большим разнообразием и свидетельствует о возросшем мастерстве поэта. В нашей следующей работе мы предполагаем рассмотреть, как рифменное богатство Рильке отражается в русских переводах.

$* * *$

1. Рожанский И.Д. Райнер Мария Рильке. Основные вехи его творческой эволюции // Рильке Р.М. Ворпсведе. Огюст. Роден. Письма. Стихи. - М.: Искусство, 1971. - С. 7-49.

2. Чайковский Р.Р., Лысенкова Е. Л. «Пантера» Р.М. Рильке в русских переводах. Магадан: АО «МАОБТИ», 1996. - 132 с. 